\title{
1 Rapid SARS-CoV-2 antigen detection by immunofluorescence - a new tool to detect
}

\section{2 infectivity}

4 Lorena Porte ${ }^{1, *}$, Paulette Legarraga ${ }^{1}$, Mirentxu Iruretagoyena ${ }^{1}$, Valeska Vollrath ${ }^{1}$, Gabriel

5 Pizarro ${ }^{1}$, José M. Munita ${ }^{2,3,4}$, Rafael Araos ${ }^{2,3,4}$, Thomas Weitzel ${ }^{1,3, *}$

$7 \quad{ }^{1}$ Laboratorio Clínico, Clínica Alemana, Universidad del Desarrollo, Santiago, Chile

$8{ }^{2}$ Servicio de Infectología, Clínica Alemana de Santiago, Facultad de Medicina Clínica Alemana,

9 Universidad del Desarrollo, Santiago, Chile

$10{ }^{3}$ Instituto de Ciencias e Innovación en Medicina (ICIM), Facultad de Medicina Clínica Alemana,

11 Universidad del Desarrollo, Santiago, Chile

$12{ }^{4}$ Millennium Initiative for Collaborative Research on Bacterial Resistance (MICROB-R),

13 Santiago, Chile

14

15 *Correspondence: L. Porte (lporte@alemana.cl) and T. Weitzel (thomas.weitzel@ gmail.com)

16

17 Abstract

The evaluated SARS-CoV-2 antigen rapid fluorescence immunoassays reliably identified

19 patients within the first 5 days of symptom onset, when respiratory secretions carried high viral

20 loads. This high performance suggests that these tests might play an important role for future

21 PCR-independent strategies to detect early or infective cases.

23 Key words: SARS-CoV-2; Covid-19; Diagnosis; Rapid diagnostic test; Antigen detection 
medRxiv preprint doi: https://doi.org/10.1101/2020.10.04.20206466; this version posted October 6, 2020. The copyright holder for this preprint (which was not certified by peer review) is the author/funder, who has granted medRxiv a license to display the preprint in perpetuity.

All rights reserved. No reuse allowed without permission.

\section{Introduction}

Since its emergence in 2019, the SARS-CoV-2 pandemic has resulted in over 30 million

26 confirmed cases and almost 1 million deaths worldwide, as of September 2020

27 (https://covid19.who.int). Early detection of cases by highly sensitive and specific real-time

28 reverse-transcription polymerase chain reaction (RT-PCR) is the currently recommended

29 diagnostic strategy [1]. However, the high cost of RT-PCR, shortage of reagents, and need for

30 trained personnel have limited the testing capacities of laboratories to provide results in a timely

31 manner [2]. Thus, alternative diagnostic tools allowing the fast testing of large numbers of

32 samples are of high priority [3]. In addition, new aspects of SARS-CoV-2 testing include the

33 ability to evaluate infectivity to help tailor control measures of known or suspected Covid-19

34 cases [4].

Rapid antigen detection tests (Ag-RDT) using immunochromatographic tests (ICT) or

36 fluorescent immunoassays (FIA) have recently become available; many of which are CE-IVD

37 licensed and some have received FDA emergency use authorization (EUA) [5]. As previously

38 suggested, FIAs are highly specific and can reach remarkably high sensitivities, if applied in

39 samples from early phases of infection or with high viral loads [6,7]. Here we present the

40 performance of two novel FIA automated antigen detection systems in samples from Covid-19

41 patients presenting within 5 days of symptom onset.

\section{Material and methods}

44 Samples derived from patients attending Clínica Alemana in Santiago, Chile, for Covid-

4519 testing. Specimens consisted of naso-oropharyngeal flocked swabs obtained by trained

46 personnel and placed in universal transport media (UTM-RT ${ }^{\circledR}$ System, Copan Diagnostics, 
medRxiv preprint doi: https://doi.org/10.1101/2020.10.04.20206466; this version posted October 6, 2020. The copyright holder for this preprint (which was not certified by peer review) is the author/funder, who has granted medRxiv a license to display the preprint in perpetuity.

All rights reserved. No reuse allowed without permission.

47 Murrieta, CA, USA). Samples were examined for SARS-CoV-2 RNA by RT-PCR assay

48 (COVID-19 Genesig ${ }^{\circledR}$, Primerdesign Ltd., Chander’s Ford, UK). Samples exhibiting exponential

49 amplification curves and cycle thresholds $(\mathrm{Ct})$ values $\leq 40$ were considered positive.

$50 \quad$ RT-PCR characterized UTM samples were aliquoted and kept at $-80^{\circ} \mathrm{C}$ until analysis by

51 the two FIA kits, "SOFIA SARS Antigen FIA" (Quidel Corporation, San Diego, CA, USA) and

52 “STANDARD ${ }^{\circledR}$ F COVID-19 Ag FIA” (SD Biosensor Inc., Gyeonggi-do, Republic of Korea).

53 Both tests detect SARS-CoV-2 nucleocapsid protein by lateral flow immunofluorescence, which

54 is interpreted by automated analysers (SOFIA 2, Quidel Corporation; F2400, SD Biosensor Inc.).

55 Both kits are CE-IVD labelled; Quidel recently received FDA EUA. Manufacturers state that

56 both tests should be performed using nasopharyngeal swabs collected from symptomatic

57 individuals within 5 days of symptom onset. The use of samples stored in certain brands of

58 transport media (including Copan UTM) is permitted for the SD Biosensor assay; the Quidel test

59 initially also allowed using UTM, but a recent instruction update discourages the use of

60 prediluted samples [8].

For the evaluation, 32 RT-PCR positive UTM samples, all collected within the first 5

62 days after symptom onset, and 32 negative specimens were selected. All positive samples were

63 from symptomatic patients, 12 negative samples were from asymptomatic patients screened

64 before surgery. Some of the positive $(n=27)$ and negative samples $(n=19)$ had been used in a

65 previous evaluation [7]. Assays were performed using the same sample aliquot, following

66 manufacturers' instructions, by the same laboratory personnel, who were blinded to RT-PCR

67 results. In brief, specimens were mixed with an extraction reagent, dispensed into the cassette's

68 sample well, and read after incubation by an instrument. All procedures, except the reading, were

69 performed under a BSL2 cabinet. Results were compared to those of RT-PCR as reference 
medRxiv preprint doi: https://doi.org/10.1101/2020.10.04.20206466; this version posted October 6, 2020. The copyright holder for this preprint (which was not certified by peer review) is the author/funder, who has granted medRxiv a license to display the preprint in perpetuity.

All rights reserved. No reuse allowed without permission.

70 method; in case of discordant results, tests were repeated. Demographic and clinical data were

71 obtained from mandatory notification forms and analysed in an anonymized manner. Statistical

72 analysis considered the calculation of sensitivity, specificity, and accuracy using standard

73 formulas, and Wilson score Confidence Interval at 95\% (OpenEpi version 3.01). Test

74 performance was evaluated for all samples and for those with high viral loads $(\mathrm{Ct} \leq 25)$, as

75 previously described [9]. Kits and analysers were provided by manufacturers at reduced costs for

76 evaluation purposes. The study was approved by the institutional review board (Comité Etico

77 Científico, Facultad de Medicina Clínica Alemana, Universidad del Desarrollo, Santiago, Chile)

78 and a waiver of informed consent was granted.

\section{Results}

The study included a total of 64 samples, 32 were RT-PCR positive and 32 RT-PCR

82 negative. The median age was 39 years (IQR 36.7-57) and 52\% were male. Median days from

83 symptom onset to RT-PCR testing of positive and negative cases were 2 (IQR 1-3) and 1 (IQR

84 0.75-4), respectively. Ct values had a median of 17.95 (IQR, 16.4-22.4); 29/32 samples (90.6\%)

85 had a $\mathrm{Ct} \leq 25$.

Both assays demonstrated an overall sensitivity $>90 \%$, reaching $100 \%$ for samples with

87 high viral loads (Table 1). False negative results were observed with the Quidel and SD

88 Biosensor assays in two and three samples, respectively, which had Cts of 30.89 to 32.57 and

89 were taken on the fourth or fifth day after symptom onset. Specificity was $96.7 \%$ for both tests,

90 i.e. both kits displayed a single false positive result, from two distinct symptomatic RT-PCT

91 negative cases. Both assays were user friendly, included ready-to-use reagents and required little

92 hands-on time. Moreover, analysers were easy-to-use, stored the results, and included options for

93 QR coding, printing, and connection to laboratory information systems. 
medRxiv preprint doi: https://doi.org/10.1101/2020.10.04.20206466; this version posted October 6, 2020. The copyright holder for this preprint (which was not certified by peer review) is the author/funder, who has granted medRxiv a license to display the preprint in perpetuity.

All rights reserved. No reuse allowed without permission.

\section{Discussion}

At present, RT-PCR is the recommended diagnostic method in patients with suspected SARS-CoV-2 infection [1]. However, material shortages and laboratory capacity

97 limitations, especially during high transmission situations, have caused significant problems and

98 led to the emergence of various new PCR-independent diagnostics [10]. Antigen-based assays

99 are among the most recent developments, but peer-reviewed evaluations of their diagnostic

100 performance are scarce. Hence, their role within the routine diagnostic workup is yet not defined

$101[9,11]$. Since antigen detection per se has a lower sensitivity than RT-PCR, it will most likely not

102 replace it [9]. However, the results of this and former studies indicate that antigen detection by

103 immunofluorescence, especially when used with an automated reader, has an excellent

104 sensitivity to detect SARS-CoV-2 in samples with estimated viral loads above $\sim 10^{6}$ copies $/ \mathrm{mL}$

105 (Ct values $\leq 25)$ [9], which are found in pre-symptomatic (1-3 days before symptom onset) and

106 early symptomatic Covid-19 cases (5-7 days after symptom onset) [9,12-14]. According to recent

107 modelling studies, elevated viral titers are associated to infectivity [15]. This is in accordance

108 with in vitro experiments, which showed no viral growth from samples with Cts $>24$ or taken $>8$

109 days after symptom onset $[16,17]$. A viral load of $10^{6}$ copies/mL has therefore been suggested as

110 the limit of infectivity for clinical practice [18]. However, until the exact threshold of

111 contagiousness is known, other authors have considered a more conservative approach (1,000

112 copies/mL) [19].

113 For samples with high viral loads both evaluated tests were $100 \%$ sensitive. In our panel

114 of positive samples, false negatives only occurred with $\mathrm{Cts}>30$, which translates to viral loads

$115<10^{4}$ for the used RT-PCR protocol [20], although this finding has to be confirmed with a larger

116 number of specimens. The high-performance value coincides with recent studies of a similar FIA 
medRxiv preprint doi: https://doi.org/10.1101/2020.10.04.20206466; this version posted October 6, 2020. The copyright holder for this preprint (which was not certified by peer review) is the author/funder, who has granted medRxiv a license to display the preprint in perpetuity.

All rights reserved. No reuse allowed without permission.

117 with automated reading (BioEasy), which demonstrated sensitivities of $100 \%$ for samples with

118 Cts $\leq 25[6,7]$ and of $98 \%$ for samples with Cts $\leq 30$ [21]. In contrast, immunochromatographic

119 SARS-CoV-2 antigen tests demonstrated lower sensitivity values of $74 \%-85 \%$ for samples with

120 Cts $\leq 25[7,22,23]$.

121 Although additional studies with larger numbers of samples are needed, the excellent

122 performance data of FIA Ag-RDTs suggest their potential use in the following scenarios, when

123 RT-PCR is unavailable or impractical: 1) closed or semi-closed remote communities such as

124 cruise ships or military camps [9], 2) High-risk congregate facilities including schools, care-

125 homes, dormitories, etc., when testing daily or every other day could reduce secondary infections

126 by $100 \%$ or $90 \%$, respectively [24], and 3) screening of asymptomatic attendees at potential

127 superspreader events, like conferences, weddings, and sports or cultural events. In the future, due

128 to their high sensitivity to detect infective patients, FIA Ag-RDTs might also play an important

129 role within "test-out" strategies, i.e. the early release of suspected cases from self-isolation or

130 shortening quarantine for proven cases.

\section{$132 \quad$ Funding}

133 This research did not receive any specific grant from funding agencies in the public,

134 commercial, or not-for-profit sectors.

136 CRediT authorship contribution statement

137 L. Porte: Conceptualization, Data curation, Formal analysis, Investigation, Methodology,

138 Project administration, Supervision, Validation, Writing - original draft, Writing - review \&

139 editing. P. Legarraga: Formal analysis, Supervision, Validation, Writing - review \& editing. M. 
medRxiv preprint doi: https://doi.org/10.1101/2020.10.04.20206466; this version posted October 6, 2020. The copyright holder for this preprint (which was not certified by peer review) is the author/funder, who has granted medRxiv a license to display the preprint in perpetuity.

All rights reserved. No reuse allowed without permission.

140 Iruretagoyena: Formal analysis, Validation, Writing - review \& editing. G. Pizarro: Data

141 curation, Investigation. V. Vollrath: Supervision, Validation, Writing - review \& editing. J.M.

142 Munita: Validation, Writing - review \& editing. R. Araos: Validation, Writing - review \&

143 editing. T. Weitzel: Conceptualization, Formal analysis, Methodology, Project administration,

144 Validation, Writing - original draft, Writing - review \& editing.

145

146 Declaration of competing interest

147 There is no conflict of interest.

148 
149 Table 1. Performance of two automated SARS-CoV-2 antigen detection assays compared to RT-PCR

\begin{tabular}{|c|c|c|c|c|c|c|c|c|c|c|c|}
\hline \multicolumn{2}{|c|}{ Antigen detection test } & \multicolumn{3}{|c|}{ RT-PCR } & \multicolumn{4}{|c|}{ Sensitivity } & \multicolumn{2}{|c|}{ Specificity } & \multirow{3}{*}{$\begin{array}{c}\text { Accuracy } \\
\%\end{array}$} \\
\hline \multirow[b]{2}{*}{ Assay } & \multirow[b]{2}{*}{ Result } & \multicolumn{2}{|c|}{ Positive } & \multirow{2}{*}{ Neg. } & \multicolumn{2}{|c|}{ All } & \multicolumn{2}{|c|}{ High VL ${ }^{a}$} & \multirow{2}{*}{$\%$} & \multirow{2}{*}{ CI95\% } & \\
\hline & & All & High $\mathrm{VL}^{\mathrm{a}}$ & & $\%$ & CI95\% & $\%$ & CI95\% & & & \\
\hline Sofia SARS & Positive & 30 & 27 & 1 & & & & & & & \\
\hline Antigen FIA & Negative & 2 & 0 & 31 & 93.8 & 79.9-98.3 & 100 & $87.5-100$ & 96.9 & $84.3-99.4$ & 95.3 \\
\hline Standard F & Positive & 29 & 27 & 1 & & & & & & & \\
\hline COVID-19 Ag FIA & Negative & 3 & 0 & 31 & 90.6 & $75.8-96.8$ & 100 & $87.5-100$ & 96.9 & $84.3-99.4$ & 93.8 \\
\hline
\end{tabular}

150 VL, viral load; CI95\%, confidence interval 95\%; Neg., negative

$151 \quad{ }^{\mathrm{a}}$ Samples with $\mathrm{Ct} \leq 25$

152 
medRxiv preprint doi: https://doi.org/10.1101/2020.10.04.20206466; this version posted October 6, 2020. The copyright holder for this preprint (which was not certified by peer review) is the author/funder, who has granted medRxiv a license to display the preprint in perpetuity.

All rights reserved. No reuse allowed without permission.

\section{References}

1. World Health Organization. Diagnostic testing for SARS-CoV-2: Interim guidance. Available at: https://www.who.int/publications/i/item/diagnostic-testing-for-sars-cov-2

2. World Health Organization. Advice on the use of point-of-care immunodiagnostic tests for COVID-19: Scientific brief. Available at: https://www.who.int/newsroom/commentaries/detail/advice-on-the-use-of-point-of-care-immunodiagnostic-testsfor-covid-19

3. European Centre for Disease Prevention and Control. COVID-19 testing strategies and objectives. 15 September 2020. ECDC: Stockholm; 2020.

4. Rhee C, Kanjilal S, Baker M, Klompas M. Duration of SARS-CoV-2 infectivity: when is it safe to discontinue isolation. 2020; https://academic.oup.com/cid/advancearticle/doi/10.1093/cid/ciaa1249/5896916

5. Foundation for Innovative New Diagnostics. SARS-CoV-2 Diagnostic pipeline 2020. Available at: https://www.finddx.org/covid-19/pipeline/

6. Porte L, Legarraga $\mathrm{P}$, Vollrath $\mathrm{V}$ et al. Evaluation of a novel antigen-based rapid detection test for the diagnosis of SARS-CoV-2 in respiratory samples. Int J Infect Dis 2020; 99:328-333. doi: 10.1016/j.ijid.2020.05.098

7. Weitzel $\mathrm{T}$, Legarraga $\mathrm{P}$, Iruretagoyena $\mathrm{M}$ et al. Head-to-head comparison of four antigen-based rapid detection tests for the diagnosis of SARS-CoV-2 in respiratory samples. Preprint doi: 10.1101/2020.05.27.119255

8. Quidel Sofia SARS Antigen FIA Package Insert. Available at: https://www.quidel.com/immunoassays/rapid-sars-tests/sofia-sars-antigen-fia

9. World Health Organization. Antigen-detection in the diagnosis of SARS-CoV-2 infection using rapid immunoassays: Interim guidance. https://www.who.int/publications/i/item/antigen-detection-in-the-diagnosis-of-sars-cov2infection-using-rapid-immunoassays

10. Cheng MP, Papenburg J, Desjardins M et al. Diagnostic testing for severe acute respiratory syndrome-related coronavirus-2: A narrative review. Ann Intern Med 13 April 2020; doi:10.7326/M20-1301 
medRxiv preprint doi: https://doi.org/10.1101/2020.10.04.20206466; this version posted October 6, 2020. The copyright holder for this preprint (which was not certified by peer review) is the author/funder, who has granted medRxiv a license to display the preprint in perpetuity.

All rights reserved. No reuse allowed without permission.

11. Dinnes J, Deeks JJ, Adriano A et al. Rapid, point-of-care antigen and molecular-based tests for diagnosis of SARS-CoV-2 infection. Cochrane Database of Systematic Reviews 2020, Issue 8. Art. No.: CD013705. DOI: 10.1002/14651858.CD013705.

12. He X, Lau E, Wu P et al. Temporal dynamics in viral shedding and transmissibility of COVID-19. Nature Medicine 2020; 26:1491-1493. doi:10.1038/s41591-020-0869-5

13. Lee CY, Lin RTP, Renia L, Ng LFP. Serological approaches for COVID-19: Epidemiologic perspective on surveillance and control. Front Immunol 2020;11:879.

14. Zou L, Ruan F, Huang M et al. SARS-CoV-2 viral load in upper respiratory specimens of infected patients. N Engl J Med 2020; 382:12

15. Larremore DB, Wilder B, Lester E et al. Test sensitivity is secondary to frequency and turnaround time for COVID-19 surveillance. Preprint doi: 10.1101/2020.06.22.20136309

16. Bullard J, Dust K, Funk D et al. Predicting infectious SARS-CoV-2 from diagnostic samples. Clin Infect Dis 2020; ciaa638. doi: 10.1093/cid/ciaa638.

17. Wölfel R, Corman VM, Guggemos W et al. Virological assessment of hospitalized patients with COVID-2019. Nature 2020; 581(7809):465-469. doi:10.1038/s41586-0202196-x.

18. Drosten C. Coronavirus Update 54 (podcast), 1 Sept 2020. Transcript available at https://www.ndr.de/nachrichten/info/coronaskript222.pdf (accessed 16 Sept 2020)

19. Jacot D, Greub G, Jaton K, Opota O. Viral load of SARS-1 CoV-2 across patients and compared to other respiratory viruses. Preprint doi: 10.1101/2020.07.15.20154518

20. Scohy A, Anantharajah A, Bodéus M, Kabamba-Mukadi B, Verroken A, RodriguezVillalobos H. Low performance of rapid antigen detection test as frontline testing for COVID-19 diagnosis. J Clin Virol 2020; doi:10.1016/j.jcv.2020.104455

21. Diao B, Wen K, Chen J et al. Diagnosis of acute respiratory syndrome coronavirus 2 infection by detection of nucleocapsid protein. Preprint doi:10.1101/2020.03.07.20032524v2

22. Mertens P, De Vos N, Martiny D et al. Development and potential usefulness of the COVID-19 Ag respi-strip diagnostic assay in a pandemic context. Front. Med. 2020; 7:225. doi: 10.3389/fmed.2020.00225 
medRxiv preprint doi: https://doi.org/10.1101/2020.10.04.20206466; this version posted October 6, 2020. The copyright holder for this preprint (which was not certified by peer review) is the author/funder, who has granted medRxiv a license to display the preprint in perpetuity. All rights reserved. No reuse allowed without permission.

211 23. Lambert-Niclot S, Cuffel A, Le Pape S et al. Evaluation of a rapid diagnostic assay for detection of SARS CoV-2 antigen in nasopharyngeal swab. J Clin Microbiol 2020; 58(8):e00977-20. doi:10.1128/JCM.00977-20.

214 24. Paltiel DA, Zheng A, Walensky RP. Assessment of SARS-CoV-2 screening strategies to permit the safe reopening of college campuses in the United States. JAMA Netw Open 2020; 3(7):e2016818 